\title{
A ARTE DA APRESENTAÇÃO DO MUNDO: SCHOPENHAUER E A ESTÉTICA DA ALEGORIA
}

ART AND REPRESENTATION OF THE WORLD: SCHOPENHAUER AND THE

AESTHETICS OF ALLEGORY

\author{
ANDRÉ LUIS MUNIZ GARCIA ${ }^{1}$ \\ Universidade de Brasília (UNB) - Brasil \\ andrelmg@unb.br
}

RESUMO: A proposta do presente artigo é contextualizar, no pensamento de Schopenhauer, traços fundamentais de sua reflexão estética sobre a alegoria. Para tanto, o artigo foi desenvolvido segundo três linhas de argumentação: (i) interpretação da alegoria no âmbito de uma reflexão simbólica da teoria da representação; (ii) a relação entre poesia e alegoria no pensamento de Schopenhauer, com destaque para uma confrontação de sua posição tanto com o primeiro romantismo quanto com o idealismo alemão; (iii) compreensão da alegoria como elemento estético de uma retórica poética do engano.

PALAVRAS-CHAVE: Schopenhauer. Linguagem simbólica. Alegoria. Mentira.

ABSTRACT: The goal of this article aims to contextualize, in Schopenhauer's thought, the fundamental features of his aesthetic reflection on allegory. In order to fulfill this task, the article was developed according to three main arguments: (i) interpretation of allegory starting from a symbolic understanding of our world representation; (ii) the relationship between poetry and allegory in Schopenhauer's thought, confronting his position with the first romanticism and with German idealism; (iii) understanding allegory as an aesthetic form of a deception rhetoric.

KEYWORDS: Schopenhauer. Symbolic language, Allegory. Lie.

\section{INTRODUÇÃO: A VERDADE SOB A FORMA (ENIGMÁTICA) DA MENTIRA}

Pelas Musas heliconíades comecemos a cantar

Elas um dia a Hesíodo ensinaram belo canto Quando pastoreava ovelhas ao pé do Hélicon divino

Esta palavra primeiro disseram-me as Deusas

Musas olimpíades, virgens de Zeus porta-égide:

"Pastores agrestes, vis infâmias e ventres só,

Sabemos muitas mentiras dizer símeis aos fatos

E sabemos, se queremos, dar a ouvir revelações"

Hesíodo, Teogonia, versos 1 e 22-28

\footnotetext{
${ }^{1}$ Professor do Departamento de Filosofia da Universidade de Brasília (UNB).
} 
Não me parece ser em virtude apenas daquela tão debatida "evidência" antropológica - a de que é inerente ao homem uma "necessidade metafísica", uma vontade de compreender a "essência íntima da natureza", uma irresistível tendência para saber "por que o mundo existiria e [por que] teria precisamente essa característica (Beschaffenheit)" ${ }^{2}$ — que se pode interpretar o motivo pelo qual A. Schopenhauer dedicou relevante reflexão sobre a forma estética da alegoria como elemento mediador privilegiado da resposta ao "enigma do mundo". No contexto da muito citada e debatida seção 17 dos Suplementos, a religião aparece como aquilo que dá corpo (discursivo) a essa inata demanda, já que, oferecendose como alternativa ao esoterismo da filosofia, permite satisfazer a necessidade do animal metaphysicum; mais precisamente: ali, a alegoria, o sensu allegorico, como escreve Schopenhauer, enquanto forma estético-discursiva do acesso ao "em si" do mundo, representa não só uma mediação alternativa ao conceito, ao modo de pensar lógico-proposicional, acessível a pouquíssimos, mas também um elemento fundamental de formação e consolidação de uma visão de mundo de massa. Muito se argumentou que a função da alegoria é positivar o recurso do homem à religião, tornando exotérico o acesso à verdade metafísica ${ }^{3}$. Ela teria assim seu valor pela consequência do que produz, não pelo que vale nela mesma, artisticamente. Quero dizer: compensaria mais analisá-la em sua função subsidiária, o que de modo algum a desmerece, pelo contrário: vista assim, a alegoria suplementa, aliás, aquilo que seria, para o Schopenhauer, o essencial, isto é, um acesso exotérico à essência metafísica do mundo. Esse artigo pretende interpretar a alegoria em virtude daquilo que ela é e pelo que ela vale, em sua forma e função estética.

Se o enigmático da existência exige, para sua adequada interpretação pelo vulgo, uma forma linguística que lhe seja consorte, portanto, uma escrita e fala alegóricas, seria também interessante avaliá-la para além do debate entre formas discursivas herméticas (esotéricas) e de massa (exotéricas), pois a relevância daquela inata demanda metafísica do homem parece adquirir sua evidência quanto mais efetivo for o próprio uso da mediação figurativa que à própria necessidade metafísica empresta corpo e alma. Ou dito de outro modo: o próprio fato de $O$ mundo "ser enigmático" e carecer de compreensão (linguagem) enquanto tal impõe uma indistinção entre "enigma" e a respectiva forma discursiva que lhe empresta este sentido, no caso, a alegórica. Enigmático é assim tanto o mundo quanto a linguagem eleita para lhe emprestar significado, e isso, não por que tal mediação estética (a alegoria) é algo de difícil apreensão — o que seria um contrassenso, já que Schopenhauer a pensa de modo exotérico —, mas por que seu uso não equivale àquele de uma mera linguagem denotativa direta, supostamente naturalista e realista.

Visto não mais sob a forma de simples incremento, o assim chamado sensu allegorico tem sua função estética confirmada por um anti-especulativo uso expositivo do enigma do mundo, isto é, ele vale, assim pretendo mostrar, como

\footnotetext{
${ }^{2}$ SCHOPENHAUER, MRV II, $\$ 17$, p. 196 (com alterações minhas). Cito o texto da tradução de Jair Barboza, mas sempre cotejando com o original em SCHOPENHAUER, 1986. Em casos de alteração, como este acima, irei indicar minha intervenção.

3 Sobre isso, ver SCHMIDT, 1986, p. 43-8, principalmente. No Brasil, há importante material produzido sobre o assunto, por exemplo: STAUDT, 2015; DEBONA, 2008. Destaco recente tese de doutoramento defendida sobre o tema, com ênfase na discussão sobre a alegoria entre as considerações religiosas e poéticas de Schopenhauer: PICOLLI, 2018.
} 
mecanismo discursivo de representação não-direta, como referência simbólicofigurativa do "em si", fato pelo qual seus termos não visam a oferecer um acesso cientificamente demonstrável do que o mundo é, mas tão somente do que esteticamente (alegoricamente) ele pode significar. Daí por quê, dando centralidade ao discurso das religiões, Schopenhauer destacou, no capítulo 17 dos Suplementos, modalidades de discursos aptos a dar conta tanto do ponto de vista metafísico (do enigma do mundo) quanto estético-formal (a alegoria sob o signo dos mistérios) da questão. Falar/escrever segundo a língua dos mistérios é falar/escrever na forma de uma linguagem não-realista, rica em figuras e figurações; é antes uma forma de subverter a paradoxal imagem do "enigma do mundo", supostamente "sem sentido", apresentando-lhe sim, pelo fato de o homem não poder deixar de buscar uma resposta pelo fundamento da existência, uma roupagem simbólica, algo cuja evidência é confirmada, segundo Schopenhauer, nos diversos modos de fabulação, das parábolas, dos provérbios barrocos, místicos, criados pelas massas.

Muito do aspecto positivo conferido por Schopenhauer à religião vem da incomensurabilidade científica do assim chamado "enigma do mundo". Limitar certos ímpetos especulativos do discurso religioso na decifração do enigma do mundo é sim, bem ao gosto do kantismo, uma das tarefas do capítulo 17 do Suplementos. O saber (enquanto conhecimento teórico, sob a forma do princípio de razão) tem que ser suspenso para dar lugar à fé em um acesso ao "em si" da natureza - esse esquema, bem conhecido do(a) leitor(a) do segundo Prefácio da Crítica da razão pura, também vale para Schopenhauer. Não confundir visão de mundo religiosa com as instituições, com sistema religioso, isso, aliás, se destaca como um outro aspecto de sua argumentação a favor de uma positivação desse modelo de representação do mundo, no qual domina o vernáculo Glaube e não Wissen. Mas levar adiante tais leituras do texto schopenhaueriano só recolocaria algumas dificuldades que esse artigo não está disposto a repisar: ter que admitir que a linguagem alegórica é apenas discurso de "segunda ordem" ocasionaria algumas dificuldades, já que, se são duas formas discursivas de acesso (uma sensu proprio e outra, allegorico), tratar-se-ia também de uma dupla modalidade da verdade? Está fora de cogitação ter que admitir que Schopenhauer também pensaria em duas ordens de verdade, já que, como ele próprio afirma naquele capítulo, o uso em sentido alegórico da linguagem "conduz justamente para onde a verdade sensu proprio também conduziria [...]" (MVR II, \$17, p. 215 [com alterações minhas]), a saber: para jogar luz à obscura questão sobre nossa enigmática existência.

Ora, essa relação hierárquica, dominante na literatura secundária, poderia ser substituída, como quer o presente artigo, por uma simples distinção entre as mediações. Se a hipótese é óbvia, quero testar se as consequências também o são. Para tanto, pretendo aqui desenvolver meu argumento seguindo três tópicos fundamentais: (i) o contexto e sentido mais precisos a partir dos quais emerge o tratamento de Schopenhauer do tema da alegoria; (ii) sua função na reflexão estética de Schopenhauer (principalmente com relação à arte poética) e (iii) que consequências desses dois tópicos podem ser extraídas para sua filosofia em geral, consequências que parecem implicar filosofia da religião e filosofia da arte, algo que, mesmo não sendo lá tão inovador, indica um modo interessante de escapar aos arremedos acometidos por Schopenhauer em relação à tradição (platônica e 
idealista) que ele tanto diz prezar. Pois devo dizer que não considero simples licença poética ou mera anedota ilustrativa afirmar, justamente como o faz Schopenhauer no segundo tomo de seus Parerga e Paralipomena (doravante P), quando novamente trata do fenômeno da religião, que a verdade ambicionada pela "metafísica do povo" (discurso religioso) nada mais seria do que "uma vestimenta alegórica (eine allegorische Einkleidung)", o que quer dizer, tal como coloca na boca de uma (já alegórica) personagem, Demópheles, que "o profundo sentido e finalidade suprema da vida só pode ser, para o povo, expresso e mantido simbolicamente [...]", dando a entender com isso que o acesso à verdade tem legitimidade metafísica exotérica justo quando toma emprestado o "traje da mentira (Gewande der Lüge) [...]" (SCHOPENHAUER, P II, p. 383 e 393, respectivamente). ${ }^{4}$

O modo como se dá o acesso e comunicação exotéricos da verdade sobre o em si do mundo não poderia mais então prescindir de um outrora antitético elemento discursivo, a mentira, tomada aqui não em seu lastreado sentido moral, mas enquanto mediação estética de narrativas religiosas (na forma de fábulas, parábolas, mistérios etc.), mediação esta que inculca um inocente enganar a quem ouve ou lê uma narrativa enigmática reveladora da verdade, tal como escreve o próprio Schopenhauer (na boca agora de outra personagem do ficcionado diálogo dos Parerga II, Philaletes), quando evoca a imagética da pia fraus de Ovídios, ilustrando com isso que aí o discurso está a se "servir da inverdade como veículo da verdade!" (Schopenhauer, P II, p. 394) — ou mesmo: "que a mais importante, suprema e sagrada verdade não pode vir à tona de outra maneira a não ser representada pela mentira" (Ibidem, p. 397). Enquanto o discurso alegórico existir

\footnotetext{
${ }^{4}$ Traduções dessa obra serão de minha autoria.

5 SCHOPENHAUER, P II, p. 397. Nas Metamorfoses, o trecho a que se refere Schopenhauer trata claramente de um inocente engano: o cenário é mítico, a mulher do nobre Ligdo, Teletusa, está grávida, e o pai, indômito pelo nascimento de um menino, jura de morte a possível filha. Ao que canta o vate romano: "Contemplado o tempo, já ela mal podia mover o peso do ventre, / quando, a meio da noite, num sonho, se apresentou, ou assim pareceu, frente a seu leito, a filha de Ínaco / rodeada do seu cortejo sagrado" (OVÍDIO, 2017, p. 517-51; aqui, livro 9, versos 685-8). A apresentação onírica do pedido furta a linguagem de um possível realismo, típico recurso da estética do ludíbrio, como será destacado mais adiante, ao pontuar a questão do engano em Schopenhauer. A deusa pede para que Teletusa "se furte às ordens do marido" (verso 697), e cheia de alegria prepara-se para o pardo, motivo do truque. "Quando a dor aumentou e a carga saiu, por si, à luz do dia / e, sem o pai saber, nasceu uma menina, / a mãe, mentindo (mentita), decidiu que como rapaz ia ser criada. Todos acreditaram e só a ama tinha conhecimento do engano (era ficti... conscia)", e daqui o contexto da famosa expressão: "Sua piedosa mentira mantinha-se encoberta pela fraude. / Era de rapaz a roupa. As feições, atribuíssem-se / a menina ou a rapaz, a ambos tornariam belos". Ibidem, versos 706-13. Muito se argumentou que a expressão pia fraus, que se tornou corrente na linguagem ordinária, mas que possuía valor fundamental para a arte poética, corresponderia a um aspecto moral da ação que, por não poder ser levada a cabo, precisaria de um meio "artificial" e "ingênuo" que a garantisse; ou seja, que a "boa fé" da intenção legitima a mentira empregada como meio. Discordo dessa interpretação, pois ela prescinde justo de pensar a mentira em seu contexto estético de criação de uma bela imagem, de um belo discurso, o que no próprio texto de Ovídio é claro ao propor que a beleza da personagem (o rebento) é garantida por uma mendacia. O fato de a deusa pedir, em sonho, para que a grávida jogue com a mentira e garanta a beleza é tema recorrente na poesia grega, basta lembrar o (citado como epígrafe deste tópico) trecho de Hesíodo na Teogonia. Que as musas e deusas gregas falam mentira é um trunfo estético-formal do próprio artista, como nos lembra Nietzsche em um pouco conhecido aforismo de Humano, demasiado humano II, Opiniões e sentenças, 188. "As musas como mentirosas "conhecemos a arte de dizer muitas mentiras" - assim cantaram as musas ao se revelarem a Hesíodo. Encontramos descobertas fundamentais quando enxergarmos o artista como enganador" (NIETZSCHE, 1995, vol. 2, p. 462 [tradução minha]).
} 
como subsidiário (estético) da necessidade metafísica do homem; enquanto existir como elemento mediador do "em si" do mundo este "véu da alegoria (Schleier der Allegorie)", então, um duplo aspecto do conhecimento conferido por esse discurso será incontornável, a saber: "uma da verdade e uma do engano (des Truges)" (Ibidem, p. 398). Essa decisiva consequência de ter que apresentar um acesso à verdade fundamental sob a forma da mentira, isto é, alcançar uma "interpretação da vida (Auslegung des Lebens)" via recurso estético ao inocente engano ensejado por modos de fala e escrita alegóricos, pressupõe, como dito acima, a compreensão daqueles outros tópicos supramencionados, para os quais esse artigo pretende oferecer uma interpretação de conjunto.

\title{
1. UMA CERTA HERANÇA ALEMÃ: ALEGORIA NO CONTEXTO DE UMA TEORIA ESTÉTICA DA REPRESENTAÇÃO
}

\author{
Anda, arauto! À tua moda \\ Pois de tempo não dispomos \\ Trata de nos descrever, \\ Já que alegorias somos \\ E nos deve conhecer. \\ Goethe, Fausto II, versos 5528-32
}

Em virtude talvez de um certo apego conteudístico, a pesquisa em torno da concepção schopenhaueriana de alegoria, tramitando entre a investigação acerca do revelar-se da verdade metafísica pela religião e pela arte, mais precisamente, pelo discurso místico e o poético, privilegia quase sempre uma exaustiva e cerrada interpretação do terminus technicus do autor, os "grandes conceitos" de seu filosofar, algo que possui sim sua importância quando se trata de estudo ad hoc; mas como se trata aqui apenas de alimentar algumas suspeitas de um estudioso não-especialista, prefiro nutrir as expectativas da leitora e do leitor com as "migalhas filosóficas" daquelas pesquisas.

Hent de Vries, em importante artigo sobre a concepção de alegoria na filosofia da religião de Schopenhauer, já chamava atenção para um paradoxal uso "profano" da alegoria com intuito de, justamente, ilustrar uma esfera "sagrada" ao discurso metafísico-religioso: a revelação (Offenbarung) da verdade, o que claramente marcaria um distanciamento de Schopenhauer da então em voga teologia especulativa, tão propalada, a seu tempo, pela filosofia da história e da religião do Hegel maduro. ${ }^{6} \mathrm{O}$ recurso sugerido por de Vries é interessante: propõe retomar as bases da estética do primeiro romantismo ${ }^{7}$, que à época (final dos anos

\footnotetext{
${ }^{6}$ Sobre isso, ver De VRIES, 1991, p. 190.

7 Já A. Hübscher havia escrito importante artigo sobre a relação de Schopenhauer com o romantismo. Segundo ele, não há dúvidas sobre influências diretas já em sua obra capital. „Kein Zweifel, Die Welt als Wille und Vorstellung' ist aus dem Umkreis der Romantik heraus erwachsen, wie es sich für das Jahrzehnt von 1810 bis 1820 schickt. [...] Romantik — als Durchgangsstufe auf seinem Wege, nicht als Vollendung seines Weges, das ist die erste Voraussetzung für jede Abschätzung von Breiten- und Tiefenwirkung seines romantischen Erlebnisses" (HÜBSCHER,
} 
de 1790) ainda era composto pelo pequeno e inspirado grupo de Jena, imbuídos da tarefa conjunta de confeccionar um projeto secular para a arte. Eram representantes de uma tradição que visualizava no uso simbólico-profano do discurso um potente mediador estético de sua mais fundamental pretensão: uma espécie de popularização do acesso ao universal, à "ideia". Um dos marcos históricos desse projeto, o manuscrito assim denominado $O$ mais antigo programa sistemático do idealismo alemão, concebido no seio do assim chamado Jena-Kreis, dá mostras da ambição:

Por último, a ideia que unifica tudo, a ideia da beleza, tomada a palavra em seu sentido superior, platônico. Pois estou convicto de que o ato supremo da razão, aquele em que ela engloba todas as ideias, é um ato estético, e de que a verdade e a bondade só estão irmanadas na beleza. O filósofo tem de possuir tanta força estética quanto o poeta. [...] A poesia adquire com isso uma dignidade superior, torna-se outra vez no fim o que era no começo - mestra da humanidade; pois não há mais filosofia, não há mais história, a arte poética somente sobreviverá a todas as outras ciências e artes. [...] Enquanto não tornarmos mitológicas as ideias, isto é, estéticas, elas não terão nenhum interesse para o povo. (SCHELLING, 1979, p. 42-3). ${ }^{8}$

Os paralelos que esse texto guarda com o insurgente romantismo já foi objeto de diversos estudos, dos quais destaco aqui os de Manfred Frank (cf. 2015; 2007). No que tange aos propósitos desse artigo, interessa-me um contexto mais particular: de imediato, o leitor ou leitora, com certa afinidade com o texto do livro terceiro d' $O$ mundo, pode notar algumas incompatibilidades entre o mencionado trecho desse projeto e a reflexão sobre a arte, mais precisamente sobre a poesia, tal como lá é empreendida por Schopenhauer; por outro lado, parece-me não poder deixar de admitir que, se há profunda discordância sobre a possível síntese entre filosofia e poesia, entre o pensar, cuja atividade representativa se dá por conceitos, e aquela outra, da poesia, feita por imagens, não se pode deixar de admitir que a poesia, para Schopenhauer, também é concebida como modelo privilegiado para a mediação do conhecimento da ideia, ${ }^{9}$ mais ainda quando se é lembrado aquele aposto: "em seu sentido superior, platônico".

A ideia é forma, mas não em sentido especulativo, a saber, das condições de conhecimento segundo o princípio de razão suficiente; ela é, no contexto do $\$ 32$ do livro terceiro d' $O$ mundo, "apenas a objetidade imediata e por isso adequada da coisa em si [...]" (Schopenhauer, MRV I, 132, p. 241). Ela representa (em sentido pleno) o em si do mundo, a vontade, sem ser dele representação (em sentido estrito), enquanto forma cognoscível do objeto. A ideia platônica é, afirma Schopenhauer, "a mais adequada objetidade possível da vontade ou coisa em si; é

1951/1952, p. 3-4). O texto ainda indica importantes "traços" filosóficos e influências do romantismo em sua reflexão sobre poesia e a música.

${ }^{8}$ Citado com pequena modificação minha a partir do original publicado em HEGEL, 1971, Werke 1, p. 235-236. Como alerta o tradutor Rubens Rodrigues, é impossível determinar a autoria do manuscrito.

9 "[...] o fim de toda arte é a comunicação da ideia [...]" (MRV I, p. 314). 
a própria coisa em si, apenas sob a forma da representação" (Ibidem, p. 242). Em comum com aquele programa do círculo de Jena, vê-se aqui a importância, mutatis mutandis, de conceber um alternativo modelo de representação da ideia, mas isso com uma enorme diferença: não se concebe uma irmandade entre poesia (arte) e filosofia, pois, para Schopenhauer, a arte jamais se fundaria em, ou seria testada por, mediações lógico-proposicionais, isto é, arte se furta a uma submissão às formas que condicionam todo o conhecimento possível (no caso, o tempo, o espaço, a causalidade e a matéria). Enquanto o mais "claro espelho do objeto" (Ibidem, p. 246), a ideia é concebida por Schopenhauer não como a formarepresentação de fenômenos, mas pura forma do "ser-objeto", o universal-doparticular, ou em outras palavras: ela refere-se não ao que cada objeto é, mas ao ser-objeto enquanto tal, representa por assim dizer a possibilidade de visualização e contemplação do universal, do "em si", como objeto, em um modelo que expõe a essência do mundo em forma-objetal. É como se a arte pudesse representar, enquanto ideia, a objetidade da "coisa em si" mesmo que, ao fazer isso, signifiquea segundo algo outro, ou seja, dizendo o singular mas querendo dar sentido a algo universal. ${ }^{10}$ E é somente assim, enfatiza Schopenhauer agora no \$35, que "concordaremos com Platão, quando atribui um ser verdadeiro apenas às ideias, enquanto às coisas no espaço e no tempo, a esse mundo real para o indivíduo, ao contrário, reconhece apenas uma existência aparente e onírica". ${ }^{11}$

A longa história de recepção, por Schopenhauer, do conceito "ideia” já foi fartamente esmiuçada, aliás com sobra de detalhes pela pesquisa-Schopenhauer brasileira, e não será aqui retomada para evitar aquele ritual mimético enfadonho, bastando, por ocasião, remeter os leitores e leitoras a esses estudos. ${ }^{12}$ Comum a esses comentários destaca-se a profunda influência (aliás omitida por Schopenhauer) do nome de F. von Schelling, considerado, ademais, um dos possíveis escritores do supracitado manuscrito sobre $O$ mais antigo programa sistemático do idealismo alemão. Sua pertinência para o presente artigo é menos por um contexto filológico, por meio do qual se mapeia, localiza e se analisa a influência de uma leitura ou discussão intertextual, e mais — o que é sempre uma decisão idiossincrática - por apresentar o híbrido espectro do debate sobre o estatuto da ideia em um domínio estético, mais precisamente, sobre o acesso ao universal via linguagem simbólica. A motivação dessa idiossincrasia não é idólatra, no entanto, tem lá sua plausibilidade filosófica: ela reside em buscar avaliar em que medida Schopenhauer mantém com (e contra) Schelling uma espécie de produtiva tensão.

\footnotetext{
${ }^{10}$ Um dos modos mais tradicionais de abordar essa questão é pela "querela" entre Schiller e Goethe sobre a distinção entre duas propostas estéticas de apresentação simbólica, a saber, entre o símbolo (apresentação do universal no particular) e a alegoria (exposição pelo particular de algo que significa o universal). Seria, claro, relevante tematizar alguns tópicos desse debate, mas isso conduziria a outros contextos e argumentos, amplos demais para a pretensão desse artigo. Para uma detalhada interpretação dessa discussão, cf. SØRENSEN, 1979, p. 632-41.

${ }^{11}$ Sobre isso, cf. Schopenhauer MRV I, p. 250.

${ }^{12}$ É reconhecida entre os pares a tese de doutoramento de Jair Barboza sobre o tema em BARBOZA, 2002, passim. Cf. também BRANDÃO, 2009, p. 13-24.
} 
Que o texto d'O mais antigo programa está sugerindo um novo modelo de representação, não mais sustentado por mediações ontológicas caducas, esse parece ser o modo interessante para se visualizar a importância de Schelling para a estética schopenhaueriana. Aquele mencionado modelo de representação aludido por Schopenhauer em sua reflexão sobre a ideia havia sido já radicalmente tratado por Schelling, a ponto de buscar uma forma de exposição plena do universal pela obra de arte que não meramente significasse, mas que fosse capaz de ser, numa unidade, a exibição do real (objeto) no ideal (absoluto) (SCHELLING, 2001, p. 27). ${ }^{13}$

Aquilo que nos comove e desperta interesse e satisfação na contemplação artística, escreve Schelling em sua Filosofia da arte, compêndio de anotações de seus cursos sobre estética em Jena (1802-3) e em Würzburg (1804-5), não são "belezas isoladas", pois "somente o todo é belo", e "[q]uem portanto não se eleva à ideia do todo, é totalmente incapaz de julgar uma obra” (SCHELLING, 2001, p. 22). Esse trecho apresenta uma intenção implícita: evitar atribuir ao discurso artístico fraca função figurativa em sua suprema tarefa de apresentação Darstellung, no original alemão - do universal da natureza (apresentação do infinito no finito, em sua terminologia técnica). Se a função estética precípua da arte é simbólica, na medida em que comporta representações e na medida em que suas representações são signos-imagens, mediações linguísticas cuja pretensão é fazer referência a algo exterior, assim, para não incorrer no equívoco de uma apresentação particularizada do universal, um modelo de representação cuja forma de significação não é "por si", mas totalmente dependente de uma realidade exterior dada ao sujeito; portanto, para evitar esse déficit de universalidade da própria linguagem simbólica, ela própria fenômeno do particular, Schelling argumenta a favor de uma absoluta autorreferência da linguagem artística, no sentido de que a arte tem que, ao significar, referir-se a si própria como ideia autônoma, representando belas imagens como um todo ideal da natureza, como uma, ele argumenta, apresentação do "absolutamente belo, do belo em si, mediante belas coisas particulares” (Ibidem, p. 68). E é para explicar essa difícil tarefa de significação universal do mundo pela arte que Schelling traz à tona uma reflexão, que se tornaria longeva, sobre a mitologia (Filosofia da arte, \$38), arte sui generis que exemplifica, segundo Schelling, a possiblidade de não suprimir o absoluto (os deuses) quando se está a assinalar, nas mais diversas modalidades poéticas, coisas particulares (no caso, as imagens naturais que o representam). A mitologia (re)aparece (pois ela consta já, como plano, do último capítulo do Sistema do idealismo alemão, de 1800$)^{14}$ como modelo estético absoluto de representação autorreferente, portanto, como arte cuja linguagem simbólica suprime qualquer possiblidade de cisão entre significação e ser, quer dizer, pela concepção schellinguiana de mitologia não se trata de conceber o simbólico como

\footnotetext{
13 "De antemão já se poderia, portanto, determinar a tarefa da filosofia da arte assim: expor no ideal o real que existe na arte. Só que a questão é precisamente o que significa expor um real no ideal, e antes de sabermos isso, não teremos ainda clareza sobre o conceito da filosofia da arte" (SCHELLING, 2001, p. 27).

${ }^{14}$ Amplo e detalhado estudo da concepção de mitologia em Schelling encontra-se em GABRIEL, 2006.
} 
significação de algo, mas sim trata-se de uma absoluta autorreferencialidade desse ato por meio do que irromper-se-ia sua autonomia: significar é ser. A mitologia é arte de "exposição do absoluto na limitação", isto é, "mediante belas coisas particulares", mas "sem supressão do absoluto. Essa contradição só é solucionada nas ideias dos deuses, que não podem eles mesmos ter novamente existência independente, verdadeiramente objetiva, senão no desenvolvimento pleno até um mundo próprio e até um todo da criação poética" (SCHELLING, 2001, p. 68), "todo" que é justamente a própria mitologia, a figuração absoluta, eterna e autônoma do verdadeiro universo em si. "Ela é o mundo e, por assim dizer, o solo unicamente no qual podem medrar e subsistir as florações da arte" (Ibidem).

A mitologia é arte absoluta no sentido de representar plena "indiferença do universal e do particular no particular", quer dizer, por ser autônoma com relação a um simples modo particular de significação. Mitologia é a forma estética, cuja demonstração científica a Filosofia da arte ambiciona, para uma teoria absoluta da representação do absoluto, cuja matéria, por sua vez, é a poesia, em suas diversas formas de manifestação (épica, lírica e drama). O modo pelo qual Schelling ilustra isso, no $\$ 38$ de sua Filosofia da arte, recorre a uma metafórica que muito provavelmente irá conduzir a atenção dos leitores e leitoras para uma passagem já supracitada de Schopenhauer: "A mitologia nada é do que o universo em traje superior (im höheren Gewand), em sua figura (Gestalt) superior, o verdadeiro universo em si, imagem da vida e do maravilhoso caos da imaginação divina (...)" (Ibidem). Mitologia é um modo de apresentação simbólica do mundo em si, do incondicionado, é uma "roupa" que permite dar total visualidade estética à verdade universal, adornando-a figurativamente, e não é sem razão que os próximos passos de seu argumento são direcionados a classificar as modalidades simbólicas de figuração do absoluto, empresa essa que traz consigo justo uma restrição à alegoria como elemento artístico mediador do universal.

Aquela exposição (Darstellung) na qual o universal significa o particular, ou na qual o particular é intuído por meio do universal, é o esquematismo.

Aquela exposição, porém, na qual particular significa o universal, ou na qual o universal é intuído por meio do particular, é alegórica.

A síntese de ambas, onde nem o universal significa o particular, nem o particular, o universal, mas onde ambos são absolutamente um, é o simbólico. (Ibidem, p. 69).

Discutido nesse passo está a complexa tentativa de conceber, pela mitologia, a exposição, a Darstellung enquanto unidade entre o aspecto concreto do simbólico (a imagem) e sua universalidade (a ideia). Útil aqui, no entanto, não são propriamente as definições de Schelling, sua "demonstração", o que já foi amplamente explorado pela bibliografia secundária, mas sim a semântica dessa passagem e, antes ainda, o contexto filosófico para o qual ela nos remete. Schelling está levando adiante aqui, como já discutido por famoso artigo de Rubens Rodrigues Torres Filho (cf. 1987, p. 128ss.), um debate in loco com a teoria da representação estética de Kant, concebida, mais precisamente, no $\$ 59$ da Crítica da 
faculdade de juízo. A relação entre linguagem simbólica e Darstellung recompõe inovadora tentativa de Kant de sensificação (Versinnlichung) de conceitos da razão (ideias); em outras palavras: o "simbólico", naquele trecho da terceira Crítica, enquanto modelo de uma teoria estética da representação, é um "novo meio" (para além dos esquematismos) através do qual a imaginação realiza as operações da faculdade de julgar expondo, exibindo o conceito na intuição.

É certo que o(a) leitor(a) familiarizado com a obra de Kant poderia se perguntar se essa operação não coincide já com aquela apresentada na primeira Crítica, na qual a mediação da relação entre as formas da intuição (espaço e tempo) e o conceito (categorias do entendimento), enquanto condição de possibilidade do conhecimento em geral, era feita também por esquemas puros da imaginação, o que permitiu lá, a duras penas, a síntese do conceito e da intuição. O problema é que nosso juízo de gosto (objeto da terceira Crítica), tal como ele se manifesta por exemplo na linguagem poética, constitui-se de uma referência ampliada à intuição empírica, a coisas particulares. Nosso juízo estético quer guardar certa referência a objetos, visando a significá-los. Isso, segundo Kant, poderia revelar então uma antinomia do gosto (\$56 e 57 da terceira Crítica), já que supostamente não seria possível, nessa remissão ampla ao particular, fundar nossos juízos estéticos em conceitos, isto é, de modo universal. É para solucionar esse impasse, fazendo uma distinção entre modos de sensificação do conceito, entre concepções de conceito e de sua referência concreta, que Kant lança mão da Darstellung como modo da representação simbólica, capaz de expor o conceito (universal) na intuição (particular), não de forma direta (demonstrando-o), mas sim, indiretamente, segundo analogias, isto é, sujeitando o universal à forma-visual, à figuração pelo particular (intuitiva) — por uma procedimento que Kant denomina ali de hipotipose ou, na equivalência em latim, subjectio sub adspectum.

Ora, se "[a] prova de nossos conceitos requer sempre intuições [...]", então, prossegue Kant ali, é preciso, com o intuito de dirimir dialeticamente aquela mencionada antinomia, conceber uma dupla forma de sua sensificação, quer dizer, uma dupla forma de o conceito poder fazer referência a objetos, de representar o que é intuível:

Toda hipotipose (apresentação [Darstellung], subjectio sub adspectum) enquanto sensificação dupla: ou esquemática, em cujo caso a intuição correspondente a um conceito que o entendimento capta é dada a priori; ou simbólica, em cujo caso é submetida a um conceito, que somente a razão pode pensar e ao qual nenhuma intuição sensível pode ser adequada, uma intuição tal que o procedimento da faculdade de juízo é mediante ela simplesmente analógico ao que ela observa no esquematismo [...]. Ou seja, este (o intuitivo) pode ser dividido em modo de representação esquemático e em modo de representação simbólico. Ambos são hipotiposes, apresentações (exhibitiones); não são simples caracteres, isto é, denotações dos conceitos por sinais sensiveis que os acompanham e que não contêm absolutamente nada pertencente à intuição do objeto [...]. Todas as intuições que submetemos a conceitos a priori são ou esquemas ou símbolos, dos quais os primeiros contêm apresentações diretas, e os segundos, apresentações indiretas do conceito. Os primeiros 
fazem isto demonstrativamente e os segundos mediante uma analogia empírica (para o qual nos servimos também de intuições empíricas) [...]. (KANT, KU, A 254-256). ${ }^{15}$

Analogias, exemplos, referências indiretas são modos de exprimir a linguagem simbólica, capaz de realizar a síntese (não-especulativa) entre conceito e intuição. É feita indiretamente, pois ela não concorda com a intuição segundo uma regra do procedimento de representação (os esquemas no tempo enquanto forma pura, à qual poder-se-ia aplicar um conceito do entendimento, da apresentação temporal do objeto), mas concorda apenas segundo "a forma da reflexão" (\$59). "Forma da reflexão" remete aqui àquele "livre jogo" da imaginação em sua representação do intuitivo (no caso, das coisas belas) sem um conceito objetivo, objeto do $\$ 35$ da terceira Crítica; ${ }^{16}$ remete-nos, portanto, àquilo que Kant concebeu como um princípio subjetivo da faculdade do juízo, que é capaz sim de estabelecer uma síntese entre sensações e conceitos, porém, sem auxílio de uma regra de determinação, pois com ele não se busca outra coisa senão julgar, estabelecer uma síntese, sem provas, entre particulares sob a forma de sua universalidade. Essa síntese aqui aludida pelo assim chamado juízo reflexionante (reflexão estética) ocorre justamente como forma não-especulativa da Darstellung, aquela modalidade estética de exposição concreta do conceito que ocorre via analogia, via linguagem figurativa, os assim chamados "exemplos", em suma: por meio de símbolos, como escreve Kant na continuidade de seu argumento na terceira Crítica \$59. "Assim um estado monárquico", comenta Kant sobre o estatuto simbólico da analogia e dos exemplos sugestionados por uma reflexão estética, "é representado por um corpo animado, se ele é governado segundo leis populares internas, mas por uma simples máquina (como porventura um moinho), se ele é governado por uma única vontade absoluta, em ambos os casos, porém, simbolicamente. Pois entre um Estado despótico e um moinho não há na verdade nenhuma semelhança, mas certamente entre as regras de refletir sobre ambos e sua causalidade" (KANT, KU, A 256-257).

Kant conclama seus leitores à investigação desse domínio estético da reflexão, como se a partir dele se pudesse descortinar um novo horizonte para a filosofia, uma tarefa indispensável se se quer compreender melhor de que modo nossa "linguagem está repleta de semelhantes apresentações indiretas segundo uma analogia, pela qual a expressão não contém o esquema próprio para o conceito" (Ibidem, A 257), isto é, não contém uma regra de determinação, "mas simplesmente um símbolo para a reflexão" (Ibidem). Essa linguagem simbólica é, aliás, o que opera, nas palavras de Kant, a necessária Übertragung (transposição), uma atividade - me permitam dizer — metafórica, que faz passar "de um objeto da intuição a um conceito totalmente diverso, ao qual talvez uma intuição jamais

\footnotetext{
${ }^{15}$ KU abrevia a Kritik der Urteilskraft (Crítica da faculdade de juízo), segundo nomenclatura utilizada pela pesquisa Kant internacional, seguido da paginação da edição da Akademie, aqui utilizada pelo tradutor desta obra para o português (e utilizada por mim), Valério Rohden.

16 Sobre isso, ver: WACHTER, 2008.
} 
poderá corresponder diretamente" (Ibidem). E seu exemplo decisivo é este: "[...] todo nosso conhecimento de Deus é simplesmente simbólico" (Ibidem). ${ }^{17}$

A teoria estética da representação está, portanto, fundada em uma potente concepção figurativa da reflexão, uma inovação da terceira Crítica que pavimentou um novo rumo para filosofia na virada do século XVIII, haja vista aqui o caso de Schelling, mas não só!

Kant já havia antevisto que "[e]ste assunto foi até agora pouco analisado [e mereceria] uma investigação mais profunda" (KANT, KU, A 257). No caso de Schelling, o simbólico abarca a unidade entre aquelas duas formas de Darstellung propostas pela terceira Crítica: uma que parte do universal, do conceito enquanto ideia, para as partes, para o múltiplo (via esquemas); e outra que, no caminho inverso, parte do indivíduo, do particular, para significar o universal (via alegoria). No entanto, na perspectiva de Schelling, ambos, esquematismo e alegoria, seriam, em si, impotentes para fazer jus a tarefa filosófica de um modelo autônomo de representação do incondicionado, tarefa que ele e seu grupo em Jena (parte, fundadores do primeiro romantismo, parte do idealismo alemão) teria conferido à arte (e não à metafísica especulativa), mais precisamente, à poética mitológica, como narra aquele "mais antigo" programa do idealismo.

O recurso à alegoria, todavia, aparece um tanto quanto deslocado do contexto dos argumentos de Kant na terceira Crítica. A solução dialética de Kant da antinomia do gosto é apresentada de modo binário, a partir de uma distinção entre dois pontos de vista (esquema e símbolo) sobre o problema da Darstellung, tornando dialeticamente distintos, e não logicamente contraditórios, os modos (tese e antítese) de conceber a sensificação do conceito. Schelling introduz a mediação da alegoria como necessária, para explicitar uma modalidade da Darstellung que havia ficado descoberta pela terceira Crítica, a saber, de significação do universal por meio de um particular, talvez tomando parte numa conhecida querela entre Schiller e Goethe sobre a distinção entre alegoria e símbolo.

Por alegoria Schelling ilustrou o procedimento simbólico (parcial) que, ao dizer algo (o particular), pretende simultaneamente significar, representar outra coisa (o universal), atitude que, assim concebida, não possui qualquer autonomia. Não há uma identidade entre particular (natureza, finito) e universal (infinito), ou seja, entre o real e o ideal, se o ato de significar, de exposição, é conjugado como ação verbal que exige "objeto direto". Assim, a linguagem continua presa à armadilha da referencialidade. A almejada autonomia da Darstellung, sua autorreferência e identidade, não autoriza reduzir o procedimento de significação do absoluto à mera alegoria, também não aos esquemas (que representam o

\footnotetext{
${ }^{17} \mathrm{O}$ (a) leitor(a) poderá notar que estou subtraindo aqui, e isso intencionalmente, a discussão sobre a dimensão ética da reflexão estética de Kant. É possível consultá-la na obra citada de A. Wachter (Das Spiel in der Ästhetik) e em outros tantos comentários à terceira Crítica, como os capítulos XII e XIII do muito citado livro de G. Lebrun (2002). Cf. também OSTARIC, 2010, p. 22-39. Considero suficiente remeter o(a) leitor(a) a esses textos.
} 
caminho inverso do alegórico) isoladamente. ${ }^{18}$ Haveria ainda um terceiro elemento, carente de prova científica, afirma Schelling, síntese que forneceria uma unidade entre esquematismo e alegoria, à qual Schelling denomina justamente símbolo, ampliando e balizando, com relação à posteridade, o campo semântico do termo tal como ele constatava em Kant.

\title{
2. ALEGORIA E POESIA NO LIMIAR ENIRE IDEALISMO E PRIMEIRO ROMANIISMO
}

\author{
É evidente que o poeta imitador \\ não tem pendor natural para tal \\ parte da alma [...] Seria justo \\ então pegá-lo e colocá-lo numa \\ posição corresponde à do \\ pintor, [...] criando obras que, \\ confrontadas com a verdade, \\ têm pouco valor [...]. Do \\ mesmo modo, diremos que o \\ poeta imitador cria uma \\ constituição má dentro da alma \\ de cada um, porque favorece o \\ que ela tem de irracional [...], \\ mantendo-se, porém, bem \\ afastado da verdade. \\ Platão, República, 605a-c.
}

Há um fio condutor comum aos posicionamentos acima mencionados que aqui valeria novamente frisar. Em Kant e Schelling, tratava-se de conceber um modelo estético capaz de enfrentar os impasses de uma teoria da representação simbolicamente fundada, pois a linguagem encontra seu limite de exposição do universal justo ali quando entra em cena a fala, a escrita, ato que, convencionalmente, guardaria estreita relação com a apresentação de significados para referentes concretos. Schelling nega a autonomia da alegoria por enxergar nela uma via frouxa do simbólico: falar do particular, mas significando algo outro, seu universal. Ele quer a síntese entre este e seu caminho inverso, com vistas a suprimir possíveis contingências da exposição da ideia à intuição, quer dizer, da apresentação do universal sob a forma-visual do particular, da imagem, da palavra. Mas o descarte da alegoria como mediador estético privilegiado de significação real do ideal por parte do projeto estético-idealista de Schelling (a dizer, seu projeto de uma mitologia como síntese entre filosofia e arte) é vivamente criticado pela tradição do primeiro romantismo, por ver ali um velado (e ilegítimo) deslocamento do conhecimento propriamente estético (via mediações exclusivamente artísticas), rumo a uma concepção científica da arte, submetendo assim o campo estético a uma gramática filosófica, conceitual, isto é, tratando a arte ainda como ancilla philosophiae. ${ }^{19}$ Com aguda reflexão sobre o papel da linguagem poética e sua

18 Sigo aqui a argumentação de Rubens Rodrigues: "Ser e significar ao mesmo tempo é a originalidade do simbólico, e somente a atenção a ambas as perspectivas evita que se desnature o mito, sacrificando o ser à significação. Não há ironia nos deuses gregos, seu sentido não reside em nenhum além exterior e longínquo - e é preciso tomar essas figuras em sua realidade própria de Darstellung absoluta para não mutilar sua verdadeira dimensão" (TORRES FILHO, 1987, p. 135136).

${ }^{19}$ Sobre isso, ver: BEHLER, 1992, p. 59ss. Ver também: SELIGMANN-SILVA, 2005, principalmente as últimas três seções do capítulo VII. 
função iminentemente alegórica ${ }^{20}$ - pois "pensando originalmente, a linguagem é idêntica à alegoria [...]" (SCHLEGEL, 2016, p. 551) — penetra-se novamente no centro da discussão sobre uma teoria estética da Darstellung, e talvez uma das máximas poéticas mais ilustrativas do primeiro romantismo, e que, simultaneamente, exibe já uma grande desconfiança com a proposta de Schelling, seja um conhecido pólen de Novalis: "Nós procuramos por toda parte o incondicionado (das Unbedingte), e tão só encontramos coisas (Dinge)" (NOVALIS, 1978, p. 413).

O componente poético que o primeiro romantismo acreditava ser necessário para a exposição (figurativa) do universal, quer dizer, da beleza, da "obra de arte que eternamente forma a si mesma" (SCHLEGEL, 2016, p. 524), como escreve F. Schlegel, compromete-se com o resgate da alegoria como elemento central de significação e representação plenas de mundo, pois, para seus adeptos, observa Márcio Seligmann-Silva, "não há poesia nem prosa puras, [...] a linguagem nunca se deixa reduzir nem à pura auto-referencialidade (se a imagem sempre é alegórica, ela sempre "está para um outro"), nem tampouco à pura denotação" (SELIGMANNSILVA, 2005, p. 313). A poesia, enquanto legítima Darstellungskunst, carece ser compreendida como exposição de sua própria busca, tradução artística de seu anseio pelo inefável, apresentação via formas estéticas do inexponível, e isso, no intuito de introduzir uma interpretação menos filosófica (leia-se: teórica [científica]) e mais artística (leia-se: estética [beleza]) da necessidade humana de dar concretude ao incondicionado, de sua crença na realidade do ideal, na intuição do "que há de mais elevado" expresso pela contemplação da bela obra de arte. "Noutras palavras: toda beleza é alegoria. O que há de mais elevado, justamente por ser inefável, só pode ser dito alegoricamente" (SCHLEGEL, 2016, p. 524). Ou como quer Novalis, acentuando a irmandade entre linguagem poética e a forma estética do enigmático, algo que pode remeter o leitor e a leitora diretamente ao tema da representação religiosa do em si do mundo em Schopenhauer.

O sentido para a poesia tem muito em comum com o sentido para o misticismo. Ele é o sentido para o próprio, pessoal, desconhecido, misterioso, que deve ser revelado, o necessariamente casual. Ele expõe o inexponível. Ele vê o invisível, sente o que não se pode sentir etc. ${ }^{21}$

O modo pelo qual o incondicionado pode ser sensibilizado/significado por um conteúdo real, isso exigiria conceber a arte como forma de expressão nãopura, condicionada, não mais incólume à própria contingência, ao caráter fragmentário da linguagem; trata-se, nos dizeres de Novalis, de atividade infinita, ${ }^{22}$ que faz confluir forma estética (alegoria) e modelo de apresentação do todo (poesia), uma atividade que exprime o universal poeticamente pelo particular, ambicionando, desse modo, sua exposição antiespeculativa pela mediação da poética do fragmento, recurso conhecido na estética do primeiro romantismo: apresenta-se o "acabado", "perfeito", o "incondicionado", via recurso à poética do que é "inacabado", "incompleto", "indeterminado". Nesse sentido, a alegoria é

\footnotetext{
${ }^{20}$ Sobre o tema da alegoria no primeiro romantismo, principalmente em F. Schlegel, ver: FRANK, 2015, p. 287-306, páginas nas quais o autor trata preponderantemente do tema.

${ }^{21}$ NOVALIS, apud SELIGMANN-SILVA, 2005, p. 315.

${ }^{22}$ Em sua interpretação sobre o objeto da filosofia, Novalis concebe, em seus Fichte-Studien, o "ser" como movimento pleno, em atividade, "vindo-a-ser", e a tarefa de compreendê-lo, por sua vez, como uma "atividade indeterminada", sendo que o saber que daí poderia emergir (filosófico) "[...] apenas [pode] ser revelado através do ser e o ser, somente através da atividade”. Cf. NOVALIS, 1978, p. 148.
} 
atividade infinita do ato de dizer o universal, do dizer o incondicionado através do que é relativo, parcial, o que, diretamente, projeta uma crítica do primeiro romantismo à tarefa do filósofo de estabelecer um modelo puro e total especulativo — da representação pela arte, como vislumbrava Schelling.

Aliás, o poeta, personagem a quem essa tradição alemã incumbiu tão difícil tarefa, parece entrar triunfante pela antiga porta da qual foi, já desde o platonismo, expulso, e não é outra a convicção que o próprio Schopenhauer nele deposita. Sua afirmação no capítulo 37 dos Suplementos é contundente nesse sentido e nos faz pensar em ressonâncias desta tradição romântica em seu pensamento estético:

Embora o poeta, como qualquer artista, exiba-nos sempre apenas o singular, o individual; ainda assim o que ele conheceu e quer propiciar-nos é a ideia (platônica), a espécie inteira; [...] aparentemente lida com o particular, mas em verdade lida com aquilo que existe em toda parte e em todos os tempos [...] a poesia nos quer fazer conhecer as ideias (platônicas) dos seres por intermédio do singular e à maneira do exemplo: a filosofia nos quer ensinar a conhecer no todo e universalmente a essência íntima das coisas que aí se exprime. (SCHOPENHAUER, MRV II, \$37, p. 512).

O propósito da poesia é mostrar-nos num exemplo "o que é a essência e existência do ser humano" (Ibidem, p. 518), afirma no supracitado capítulo, e a primazia do drama trágico é para ele indiscutível. Se, por um lado, a irredutível posição de Schopenhauer segundo a qual a tarefa da arte poética é o conhecimento intuitivo da ideia, posição que o aproximava do modelo de representação estéticoidealista de Schelling, por outro, a dissociação rigorosa entre mediação filosófica (conceito) e artística (alegoria) acentua a impossibilidade de demonstração do acesso ao "enigma do mundo" pela poesia, já que ela não pode ser subsumida sob a forma do fazer filosófico (conhecimento do universal pelo princípio de razão). Se a exposição simbólica do universal é possível, ela só pode ser feita na forma do exemplo, do particular, ou seja, só pode ser alegoricamente fundada, e isso a favor dos românticos, também próximo a Kant — mas contra Schelling. O símbolo, aliás, representante em Schelling da unidade entre esquemas e alegoria, se torna uma forma "bastarda" de alegoria no livro III d' O mundo (\$50). É nesse livro aliás que Schopenhauer dá mostras de sua posição limiar entre idealismo (no caso, de Schelling) e o primeiro romantismo (com Novalis e Schlegel).

A reflexão schopenhaueriana sobre o estatuto da alegoria para a arte é amplo e pretende percorrer não só a poesia, mas também a pintura, por exemplo. Quem já se deparou com as seções finais do livro III d' $O$ mundo pode ter dificuldades, como eu, com a reflexão feita por Schopenhauer em torno do tema da alegoria, falo aqui de certa variação do seu valor para as artes plásticas e para a poesia. Schopenhauer é categórico: o uso da alegoria na pintura deve ser rechaçado, já que a pintura dá ao artista o intuitivo e, ao se valer da alegoria na composição pictórica, o artista conduz o conteúdo sensível ao conceito, fato que, no caso da poesia, não ocorre, pois aqui, afirma Schopenhauer, "a relação é inversa: [na poesia] o que é dado imediatamente em palavras é o conceito, e o próximo passo é sempre ir deste ao intuitivo, cuja exposição tem de ser executada pela fantasia do ouvinte" (SCHOPENHAUER, MRV I, p. 317). Com sutil, porém relevante, contraposição a Schelling, a poesia parte de conceitos, de palavras abstratas (sua matéria), em direção ao imediatamente intuitivo, a ideia (o "serobjeto"), e para tanto se vale justo de um procedimento alegórico para significar algo outro daquela universalidade abstrata (o conceito). 
O erro do uso da alegoria na pintura (que, no fundo, trata-se de uma crítica ao artifício retórico, pela pintura, da ekphrasis) estabelece, por sua vez, claro distanciamento da estética de J. J. Winckelmann, para quem as imagens, quanto mais adquirem a forma de conceitos gerais, tanto mais conseguem expor com universalidade um modelo ideal de beleza. Nos manuscritos que compõem seus Pensamento sobre a imitação das obras gregas na pintura e na escultura, encontrase sua conhecida proposta de fundir o trabalho imagético do poeta com aquele do pintor e do escultor. O artista plástico, segundo Winckelmann, "busca se mostrar tal como um poeta, pintando figuras por meio de imagens, isto é, alegoricamente" (WINCKELMANN, 2002, p. 55). Alegoria é uma mediação, um procedimento estético empregado para aludir a conceitos através de imagens, pois apenas mediante conceitos apresenta-se "a capacidade [humana] de sentir (empfinden) o belo na arte", permitindo assim com que imagens operem uma transcendência (Ibidem, p. 212) ${ }^{23}$ As deficiências das artes plásticas na Grécia clássica teriam sido supridas com o contínuo exercício de imitação, pelo pintor e escultor, da atividade alegórica do poeta grego, imbricando poesia e artes plásticas num mesmo impulso artístico.

Essa interpretação já havia sido alvo de conhecida crítica "iluminista" por parte de G. E. Lessing no início de seu Laocoonte ou sobre os limites da pintura e da poesia ${ }^{24}$, e com ela parece consentir Schopenhauer no livro III d'O mundo. Aquilo que a ideia "representa" — a própria forma do em si do mundo - é perdida quando tornada conceito pela imagem pictórica, pois perder-se-ia aí a própria ideia, "o absolutamente intuitivo" (\$49), e com isso também a possibilidade de um acesso artístico à verdade universal. A máxima horaciana - Ut pictura poiseis -, tão influente na conquista do espaço pictórico iniciada por Giotto e que recebe na estética de Winckelmann um acabamento crítico, é rechaçada. Estaria Schopenhauer assumindo uma posição demasiadamente iluminista, ao não querer o contágio da alegoria pictórica na poesia, tal como Lessing, que quis privar o drama (vide o exemplo de seu Natan, o sábio) da influência das artes escultóricas? Impossível destinar devida atenção a essa questão aqui.

Arte iminentemente intuitiva é a poesia, na qual unicamente a alegoria pode combinar, com a ajuda da fantasia, a imagem da "universalidade transparente e abstrata dos conceitos" com uma referência intuitiva imediata, ou seja, obtendo dessa universalidade "um precipitado concreto, individual, [a saber,] a representação intuitiva” (SCHOPENHAUER, MRV I, p. 321). Todas as ideias, todos os graus de objetivação da vontade, do "em si" na natureza "são exponíveis pela

\footnotetext{
${ }^{23}$ A mitologia grega tal como concebida pela poesia épica de Homero é, nesse sentido, exemplar para Winckelmann. Baseado nela a pintura grega teve seu grande e triunfante desenvolvimento, como ele próprio escreve: „Im Altertume hingegen war eine jede Vorstellung der Geschichte einer Gottheit in dem geweihten Tempel auch zugleich als ein allegorisches Gemälde anzusehen, weil die ganze Mythologie ein Gewebe von Allegorie war. Homers Götter, sagt jemand unter den Alten, sind natürliche Gefühle der verschiedenen Kräfte der Welt; [...] "E o complemento desse argumento é bastante relevante para se pensar a proximidade entre poesia e pintura na Grécia clássica: „Das Gemälde des Parrhasius wird allezeit ein Beweis bleiben, dass die Alten gelehrter als wie in der Allegorie gewesen“. Ibidem, p. 138-9.

24 "A ofuscante antítese do Voltaire grego [subent. Winckelmann], que a pintura seja uma poesia muda e a poesia uma pintura falante, não se encontra por certo em nenhum manual de ensino. Era uma ideia, como muitas outras que Simônides tivera, cuja parte verdadeira é tão evidente que cremos ter de passar por cima do falso e do indeterminado que ela traz consigo. No entanto os antigos não o ignoraram, mas, ao restringir o julgamento de Simônides sobre o efeito das duas artes, não se esqueceram de precisar que, não obstante a semelhança desse efeito, elas assim são diferentes tanto nos objetos como no modo de sua imitação [...]. [...] [Foi uma falsa interpretação que] deu origem na poesia à mania da descrição e na pintura a da alegoria [...]" (LESSING, 2016, p. 337).
} 
poesia" (Ibidem, 322), isto é, a linguagem alegórica da poesia é responsável por operar a adequada mediação estética para a apresentação do em si do mundo; é capaz de tornar conceitos (palavras abstratas) intuições da essência metafísica do mundo, do incondicionado, e nisso Schopenhauer enxerga o próprio desenvolvimento artístico das modalidades de composição poética: a poesia descritiva (narrativa histórico-poética); a poesia épica e, por fim e no mais alto grau de evolução dessa arte, a exposição pela lírica e pela tragédia, esta, por sua vez, "o ápice da arte poética” (Ibidem, 333).

\title{
3. DOUTA IGNORÂNCIA: ALEGORIA E A ESTÉTICA DO ENGANO
}

\author{
A isto se relaciona, de igual \\ maneira, a ocasional \\ vontade de o espírito se deixar \\ iludir, talvez \\ pressentindo travessamente que \\ as coisas não são assim, \\ de que apenas se convenciona \\ que sejam assim, \\ um gosto na incerteza e \\ ambiguidade, um jubiloso \\ fruir da arbitrária estreiteza e \\ descrição \\ de um canto, do extremamente \\ próximo, da fachada, \\ do que é ampliado, diminuído, \\ deslocado, embelezado [...] \\ Nietzsche, Para além de bem e \\ mal, 230.
}

A forma poética, suas variantes métricas e rítmicas, sua força imagética, acomete o(a) ouvinte, o(a) leitor(a) de um arrebatamento sedutor, consegue fundir nele(a) uma significação do ser-objeto, um "sentido real" (a expressão é de Schopenhauer) dos diversos graus de objetivação da vontade, transpondo — num procedimento que só faz sentido se não for mediado por "por quês" - a palavra abstrata em intuição imediata. Aqui, no entanto, caberia uma pergunta: mas de que modo concebe essa "imediatez", já que ao longo de todo seu argumento Schopenhauer está a supor um procedimento, uma mediação? Foi frisada, ao longo deste artigo, uma mediação (alegoria) para o imediato intuitivo, para a ideia. Desse modo, o que quer dizer propriamente essa imediaticidade? Acesso direto? Supressão do conceito como exclusiva forma de mediação? Mas não seria um tanto quanto problemático, depois desse longo percurso, assumir, em Schopenhauer, o registro simbólico da alegoria enquanto apresentação direta, denotativa, uma referência objetiva ao em si? É preciso recapitular um tema central na argumentação de Schopenhauer, a fim de jogar luz a esse questionamento; falo aqui de um resgate do entendimento de Schopenhauer da mediação estética da alegoria em seu assumido papel de "mentira" (poética).

No capítulo 37 dos Suplementos, o impactante procedimento estético da poesia é descrito como "misterioso lenocinium", pois através de técnica ilusória (a versificação poética) "pensamentos distorcidos e falsos ganham [...] uma aparência de verdade" (SCHOPENHAUER, MRV II, p. 514). Reconhece-se já essa estratégia, 
ela está presente, como acima mostrado, na reflexão de Schopenhauer sobre o estatuto da alegoria na visão de mundo religiosa. Lá se dizia: é como se a verdade pudesse ser vestida com o "traje da mentira", considerando-se mentira não em seu sentido moral ou epistêmico, mas sim enquanto mediação estética ilusionista, consorte à própria forma estética da linguagem sensu allegorico. A ilusão (fundamental para satisfação da necessidade metafísica do homem) gerada pela religião seria esta: supor alcançar efetivamente a essência metafísica do mundo, abandonando a universalidade abstrata do conceito para experimentar, sob a forma da figuração mística, uma intuição da vontade. Esse esquema vale também para a poesia.

Em suas preleções sobre estética na Universidade de Berlim, publicadas sob o título Metafísica do belo, Schopenhauer (re)afirma a tese segundo qual todo grande poeta "tem o dom do intuitivismo", para o que destaca o nome de Dante, exemplo do "tipo" poeta, já que a grandeza de sua poesia residiria em "possuir a verdade do sonho", e ele complementa: "Dante nos permite coisas inimagináveis, como em sonho; elas nos iludem justamente assim" (SCHOPENHAUER, MB, p. 198). Em primeiro plano está a estética barroca do sonho como recurso poético para interpretação da vida a partir do metro da ilusão, amplamente divulgada também pelo barroco alemão, ${ }^{25}$ mas que certamente tornou-se canônica na literatura na boca da personagem Segismundo, retratado na comédia $A$ vida é sonho de Calderón de La Barca — aliás, autor dileto de Schopenhauer: "Que é a vida? Um frenesi. / Que é a vida? Uma ilusão, / uma sobra, uma ficção; / o maior bem é tristonho, porque toda a vida é sonho, e os sonhos, sonhos são" (DE LA BARCA, 2007, p. 73). Sobreposto esse recurso barroco à poesia de Dante, nota-se a estética do arrebatamento ilusório das imagens alegóricas, ao fazer o(a) leitor(a) imaginar "coisas inimagináveis". A fantasia opera, portanto, pela mediação do sonho, uma realidade que de outro modo não seria acessível, e justo a essa realidade captada por procedimentos ilusórios Schopenhauer denomina ali: verdade onírica. O que esta expressão tem de valioso para uma estética da alegoria precisaria ser discutido a parte, em artigo mais audacioso e esmerado do que consta destas considerações finais.

Talvez aqui, no âmbito de uma verdade onírica, poesia e misticismo possam, como já queria o primeiro romantismo, compartilhar o mesmo leito. Distantes de uma linguagem realista, poeta e místico optam por um recurso estético à "linguagem onírica", o que acentua a rejeição a um mero referencialismo (a linguagem buscando significar estruturas extralinguísticas), permitindo, isto sim, como em nossos sonhos, uma (como já propunha Novalis) "significação livre"26. À guisa de uma conclusão seria importante apresentar algumas consequências dessa posição schopenhaueriana, um tanto quanto paradoxal, deve-se dizer, pois Schopenhauer parece assumir aí que há um verdadeiro acesso ao em si do mundo pela poesia, mas isso sob a seguinte condição: é necessário assumir certa atração

\footnotetext{
${ }^{25}$ Sobre isso, ver: BARNER, 2002.

26 A confrontar com a interpretação que lhe empresta Novalis: "O sonho é frequentemente significativo e profético, porque é um efeito da natureza da alma - e portanto consiste na ordem de associação - Ele é significativo como poesia - mas também devido a isso, significativo de modo irregular, totalmente livre". Citado por SELIGMANN-SILVA, 2005, p. 313 (nota 10).
} 
lúdica exercida pelo poema, que nos atrai e nos conduz pelo encanto de uma inocente mentira - aludindo aqui a já citada pia fraus —, ou seja, sob o manto de um procedimento estético ilusionista que nos seduz e engana, no sentido de fazer com que algo passe despercebido, sem que careçamos saber seu porquê e seu como. E de relance vemo-nos lançados aos bastidores do clássico tema do poeta como mentiroso, como enganador.

É conhecida a radical oposição de Sócrates à poesia homérica enquanto elemento formador da cultura grega. A objeção, que é abertamente problematizada nos livros II, III e $\mathrm{X}$ da República, introduz alguns elementos úteis para a compreensão daquilo que em Schopenhauer aparece como elogio estrito ao uso da mentira no sentido de ser um poderoso recurso estético de comunicação da verdade. Ao citar Homero (mas também os tragediógrafos!) como modelo de discurso que privilegia a mentira, em sua ilusória identificação entre o mundo e discurso (poético), Sócrates afirma diretamente a Adimanto:

[...] Ninguém de bom grado aceita ser enganado ( $\psi \varepsilon v ́ \delta \varepsilon \sigma \theta \alpha \iota)$ na parte mais importante de si mesmo e sobre questões muito importantes... Ao contrário, mais que tudo, temem ter a mentira lá instalada. [...] É que pensas que estou falando algo solene... Mas estou falando que deixar-se enganar em sua alma e

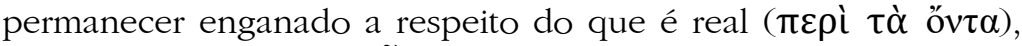

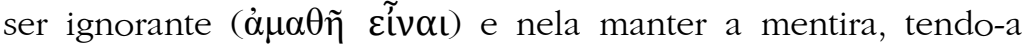
como coisa sua, é o que menos admitiriam e mais odiariam [os homens] em tal situação. (PLATÃO, A república, 382a-b)

A mentira deve ser banida da cidade justa senão porque ela engana e faz permanecer ignorante aquele que por ela é cultivado. A relação intrínseca entre engano e ignorância é decisiva para a compreensão do estatuto da mentira na poesia, já que implica a comunicação e apreensão de conteúdos sobre os quais não se carece perguntar pelo "o que é". Pela mentira não se legitima o saber, já que mentir e enganar são atitudes que se contrapõem diametralmente à verdade, e a verdade é o que não nos passa percebido $(\dot{\alpha} \lambda \hat{\eta} \theta \varepsilon 1 \alpha)$. Nesse contexto, a função moral negativa da poesia é testada: censura-se ao poeta sua tarefa de educador, já que promove um lógos, um discurso, que prescinde da verdade; ele cultivaria uma forma de vida que afirma a ignorância. Sua "injustiça" (aspecto moral) assenta-se no uso desregrado da mentira como mediadora daquilo que ambiciona comunicar e ensinar. A poesia é, por definição, causa de corrupção da pólis justa por dissimular o saber, o conhecimento, via recursos poético-retóricos, uma vez que torna "o que é real" consorte a imagens, a "verossimilhanças". A poesia, assim, é reprovada como promotora da padeia grega justo por permitir a ignorância (o "deixar-se-enganar" sobre o ser em si das coisas); a educação pela poesia flerta com o engano e a mentira, o que nos obrigaria a reconhecer a necessidade de "certa" ignorância na construção e consolidação da cultura grega. Recorde-se aqui, como exemplo, daquele elogio de Sócrates a Estersícoro no Fedro, por ter composto uma justa réplica (o que, no entanto, o levou à cegueira) às falsidades contatadas por Homero sobre Helena, alegando: "não é verídica esta versão / não andaste em naus bem cobertas / não vieste às torres de Troia" (PLATÃO, Fedro, $243 a-b)$. Por cultivar mentiras, ludíbrios, enganos, a poesia é responsável pelos 
vícios, pelos males, ali onde reina a ignorância. O poeta é sim "capaz de causar dano às pessoas de bem" e nisso "está o maior perigo" (PLATÃO, A república, 605c). O livro X da República tem conhecido desfecho sobre o assunto: no lugar da poesia é eleita a filosofia, legítima guardiã da paideia.

Nada mais estranho, portanto, ao platonismo do que o resgate de uma forma estética ilusionista - no caso, a alegoria — para mediar a relação do homem com aquela face profunda e essencial do mundo à qual visa apreender ${ }^{27}$. Mas essa licença artística não é mais tabu em alguns casos da estética alemã pós-terceira Crítica. Só para ficar aqui com um caso, aquele do primeiro romantismo: nele o acesso privilegiado da filosofia à ideia é rechaçado, algo amplamente assumido por correntes estéticas alternativas ao idealismo (leia-se Hegel, pois Schelling é um caso-limite). O quanto a ironia de Schlegel e Novalis, por exemplo, à pretensão de sistematização do absoluto pelo discurso científico-filosófico; o quanto suas estratégias estéticas de retomada de uma linguagem mitológica, onírica, barroca, para fins de expressão daquilo que transcende ao homem, e que por isso mesmo tanto o instiga; em suma: o quanto isso influenciou o primeiro romantismo, careceria de outro estudo à parte. $^{28}$ Mas não resta dúvida quanto ao recrudescimento levado a cabo por procedimentos estéticos tão estranhos ao cânone filosófico (idealismo), quero dizer, à reflexão especulativa, oriundos de profundo estudo da arte greco-romana, a contar pela atração dos românticos por recursos ilusórios que despertam no(a) ouvinte e no(a) leitor(a) um certo prazer pelo deixar-se enganar, um "prazer na ilusão" (a expressão é de um jovem e voraz leitor de Schopenhauer - Nietzsche). ${ }^{29}$ Quanto ao elogio do engano enquanto alternativa poética à "verdade" (especulativa) dos filósofos, permitam-me lembrar aqui um espirituoso pólen de Novalis publicado, em 1798, na revista Ateneu.

Quanto mais ignorante se é por natureza, tanto mais capacidade para o saber. Cada conhecimento novo faz uma impressão muito mais profunda, mais vívida. Observa-se isso claramente ao ingressar numa ciência. Por isso através do excessivo estudar se perde capacidade. É uma ignorância oposta à primeira ignorância. Aquela é ignorância por deficiência - esta por excedência de conhecimento. Esta última costuma ter os sintomas do ceticismo É porém um ceticismo spurius - por fraqueza indireta de nossa

\footnotetext{
${ }^{27}$ Contra-ataque a esse posicionamento teve aliás conhecido encaminhamento na estética de Hegel, não só em virtude de sua crítica à mediação alegórica, mas, principalmente, em sua crítica à pretensa autossubsistência do ilusionismo, de suas categorias formais e consequências artísticas, na estética. "[...] parece que sempre permanecerá prejudicial para a arte o fato de necessitar do engano [Täuschung], mesmo que de fato se submeta a fins sérios e produza efeitos sérios. Pois o belo possui sua vida na ilusão [im Scheine]. Mas reconhece-se com facilidade que um fim último verdadeiro em si mesmo não precisa ser produzido por meio do engano [Täuschung]. E mesmo que por meio dele a arte consiga aqui e ali atingir algum fomento, isso só poderá acontecer de modo restrito; e mesmo assim o engano [Täuschung] não poderá valer como o meio mais adequado. Pois o meio deve ser adequado à dignidade da finalidade, sendo que a ilusão [Schein] e o engano [Täuschung] não podem gerar o verdadeiro, mas somente o verdadeiro pode gerar o verdadeiro" (HEGEL, 2015, p. 30. Cotejado e com alterações minhas a partir da edição alemã: HEGEL, 1971, Werke 13, p. 17).

${ }^{28}$ Importante citar, nessa direção, a interpretação dessa temática por Karl Bohrer (1989).

${ }^{29}$ Dentre inúmeras passagens, ver Nascimento da tragédia, seção 12. In: NIETZSCHE, 1999, vol. 1, p. 83.
} 
faculdade de conhecer. Não se está em condições de penetrar a massa e vivificá-la completamente em forma determinada - a força plástica não é suficiente. Assim o espírito de invenção de cabeças jovens, e dos exaltados - assim o afortunado golpe de mão do iniciante, ou do leigo rico de espírito, tornam-se facilmente explicáveis. (NOVALIS, 1988, p. 87).

Não é mais estranho ao ouvido de um cultivado(a) autor(a) ou leitor(a) do início do século XIX a frase de Schopenhauer, segundo a qual a verdade pode ser comunicada, com certa força de atração, por uma inverdade; ou que a verdade é acessada, no caso da linguagem alegórica, sob "o traje da mentira”. Mencionada já por Jair Barboza, e mesmo considerando-se as intransponíveis divergências argumentativas e conceituais, não é estranho, por exemplo, também ao jovem Schelling, escrever, próximo ao ano daquele supracitado pólen de Novalis, no seu Sistema do idealismo alemão, que a função simbólica, uma vez expressão do que é finito (pela linguagem ordinária), mente (lügt), engana-nos sobre a apresentação de um "infinito sensível"30. É certo que sua pretensão especulativa em demonstrar o possível acesso estético, pelo símbolo (e não pela alegoria, exclusivamente), à ideia, ao absoluto, derraparia num verdadeiro saltus mortalis, caracterizado pela lacuna entre a finitude e particularidade semiótica do símbolo e a incomensurabilidade semântica do infinito. Mas quando se trata de expor o inexponível, o deixar algo passar despercebido é recurso estético subjacente, contagioso. Admitir o "fingimento" (a expressão é de Jair Barboza) como estratégia para apresentar a concreção sensível do universal soa conhecida retórica romântica para exaltar os limites de compreensão do incompreensível (absoluto), e Schelling não parece ter deixado de perseguir tal solução quando insistiu na centralidade da linguagem do mito como modo privilegiado de apresentação estética do mundo, mas isso, sem se dar conta de que o problemático estava em outro lugar, a meu ver, na compatibilização entre filosofia e poesia, entre reflexão especulativa (teoria) e estética (arte) ${ }^{31}$. Leia-se, por exemplo, quão mais lépido escreve Schopenhauer, no segundo tomo dos Parerga, sobre a pretensão da mitologia de propiciar aos ouvintes (gregos) um acesso alegórico aos "proto-tipos de todas as coisas e relações".

Mais do que qualquer outra a mitologia dos gregos sempre deu estofo a interpretações alegóricas, pois ela convida a isso, porquanto empresta esquemas para a sensificação [Veranschaulichung] de quase todos os pensamentos fundamentais, sim, ela contém de certa maneira os proto-tipos [Urtypen] das coisas e relações, que justamente transparecem [durchscheinen] sempre e em todo lugar como tais; ela surge propriamente do impulso lúdico dos gregos de a tudo personificar. Por isso os mitos foram já compreendidos, desde os mais antigos tempos, já desde Hesíodo, alegoricamente. Assim, por exemplo, são na verdade apenas alegorias morais quando ele (Teogonia, versos 211 ss.) menciona as crianças da noite e logo adiante as crianças de Éris, sendo elas: esforço, dano, fome, dor, luta, morte,

\footnotetext{
30"É no fingimento (na mentira) do símbolo que a grandeza relativa devém um "espelho" da grandeza absoluta, da infinitude" (BARBOZA, 2002, p. 213).

31 Tento mostrar como Nietzsche se atentou para esse problema e procurou enfrentá-lo em: GARCIA, 2017.
} 
contenda, mentiras [Lügen], injustiça, desgraça e juramento. [...] Também para todo sistema cosmológico e metafísico há de se encontrar, pela mesma razão, uma alegoria existente na mitologia. (SCHOPENHAUER, P II, pp. 482-3).

Ali onde a filosofia não prospera na satisfação da necessidade metafísica do homem, das massas, isto é, na exposição intuitiva do em si do mundo; ali onde mediações lógico-proposicionais encontram seu limite; justo aí entra em cena a tarefa lúdica da poesia, das mediações estéticas, a manifestar sob a forma alegórica da verossimilhança, da aparência da verdade, as protoformas das coisas.

Sim, Schopenhauer assume aquele esoterismo platônico de acordo com o qual uma linguagem simbólica, um discurso figurativo é "ignorante" quanto ao manejo rigoroso do conceito e suas consequências. Mas a ignorância é aqui condição, e não déficit, do uso estético da linguagem (seja poética ou religiosa), pois é nela que se encontra o critério de satisfação da necessidade metafísica do homem, uma espécie de phármakos (para usar, aliás, uma expressão do próprio Platão ${ }^{32}$ ) útil e válido para promover certo contentamento no homem ${ }^{33}$, em virtude de sua "fáustica" busca pelo "ideal", pelo acesso ao que lhe transcende, via sonho (ilusão) do imutável e divino. ${ }^{34}$ Quando essa pia ignorância, inerente à revelação religiosa da verdade, está tão próxima da arte poética (o que as aproxima é o sensu allegorico); ali onde o ilusionismo poético confunde-se com a forma antinaturalista, antirrealista, enigmática dos mistérios, como é o caso com a mitologia, ora, justo aí o saber filosófico é barrado e taxada sua inconveniência e impropriedade, e em seu lugar uma experiência artística, simbólica, é convocada, uma via ilusória da verdade - a "verdade onírica" - , pelo que nos deixamos enganar inocentemente acerca da essência do mundo, sim, um ludíbrio momentâneo, mas desejado e afirmado de modo declaradamente exotérico agora como via da "resignação, [...] [da] renúncia, não apenas da vida, mas de toda a vontade de vida mesma" (SCHOPENHAUER, MRV I, p. 333). Se a poesia, ali onde ela se torna uma práxis religiosa, quando ela se torna mitologia; se ela se encontra então arraigada às experiências e vivências mais elementares de um povo, sendo o poeta seu espelho, não teríamos aqui a mentira, contada por uma linguagem poético-alegórica pungente, operando uma função mediadora da redenção? De uma redenção, pela poesia, estética - e não... ascética?

\section{REFERÊNCIAS BIBLIOGRÁFICAS}

BARBOZA, Jair. Infinitude objetiva e estética: natureza e arte em Schelling e Schopenhauer: São Paulo: Editora Unesp, 2002.

${ }^{32}$ Cf. PLATÃO, A república, 389b.

${ }^{33}$ Contra uma referência direta, que beneficiasse uma compreensão exotérica da verdade pela linguagem alegórica, Schopenhauer afirma no capítulo 17 dos Suplementos: "A verdade não pode aparecer nua diante do povo" (SCHOPENHAUER, MRV II, p. 202).

${ }^{34}$ Esse, aliás, um dos Leitmotiven do Fausto II, que pretende cantar, já no seu início, a "ânsia humana", como espelho refletindo, a vida. "Surge magnífico o arco multicor! / Nítido ora, ora no éter se espalhando, / Imbuindo-o de aromático frescor. / Vês a ânsia humana nele refletida; / Temos, no espelho colorido, a vida" (GOETHE, 1997, p. 210 [versos 4725-27]). 
BARNER, Wilfried. Barockrhetorik: Untersuchungen zu ihren geschichtlichen Grundlagen. Tubingen: Niemeyer, 2002.

BEHLER, Ernst. Frühromantik. Berlin/New York: Walter de Gruyter, 1992.

BOHRER, Karl. H. Die Kritik der Romantik. Der Verdacht der Philosophie gegen die literarische Moderne. Frankfurt am Main: Suhrkamp, 1989.

BRANDAO, Eduardo. A noção de idéia em Schopenhauer à luz da filosofia de Schelling. In: WERLE, Marco A. et al. (Orgs.). Arte e Filosofia no Idealismo Alemão. São Paulo: Barcarolla, 2009.

DE LA BARCA, Calderón. $A$ vida é sonho. Trad. Renata Pallottini. São Paulo: Hedra, 2007.

DE VRIES, Hent. Zum Begriff der Allegorie in Schopenhauers Religionsphilosophie. In: SCHIRMACHER, Wolfgang (Hsg.). Schopenhauer, Nietzsche und die Kunst. Band 4. Wien: Passagen Verlag, 1991.

DEBONA, Vimar. As formas da razão no pensamento de Schopenhauer e a possibilidade de uma razão ético-mística. Dissertação de Mestrado em Filosofia. Pontifícia Universidade Católica do Paraná. Curitiba, 2008.

FRANK, Manfred. Auswege aus dem deutschen Idealismus. Frankfurt am Main: Suhrkamp, 2007.

Einführung in die frühromantische Ästhetik: Vorlesungen. Frankfurt am Main: Suhrkamp, 2015.

GABRIEL, Markus. Der Mensch im Mythos: Untersuchungen über Ontotheologie, Anthropologie und Selbstbewusstseinsgeschichte in Schellings Philosophie der Mythologie. Berlin/New York: Walter de Gruyter, 2006.

GARCIA, André L. M. O teórico e o antiteórico ponto de vista de Nietzsche sobre a ciência: discutindo com a interpretação naturalista. Revista Limiar, v. 4, 2017.

GOETHE, Johann Wolfgang von. Fausto. Trad. Jenny Klabin Segall. Belo Horizonte: Editora Itatiaia, 1997.

HEGEL, Georg Wilhelm Friedrich. Werke. Frankfurt am Main: Suhrkamp, 1971.

2015.

Cursos de estética. Vol. I. Trad. Marco Aurélio Werle. São Paulo: Edusp,

HÜBSCHER, Arthur. Der Philosoph der Romantik. Schopenhauer-Jahrbuch, Band $34,1951 / 1952$.

KANT, Immanuel. Crítica da faculdade de juízo. Trad. Valério Rohden et al. São Paulo: Forense Universitária, 2012.

LEBRUN. Gérard. Kant e o fim da metafísica. São Paulo: Martins Fontes, 2002.

LESSING, Gothold. E. Laocoonte: ou sobre os limites da pintura e da poesia. In: LESSING, G., E. Obras. Trad. Jacó Guinsburg et al. São Paulo: Perspectiva 2016. 
NIETZSCHE, Friedrich. Sämtliche Werke: Kritische Studienausgabe in 15 Bänden. Band 1. Hg. G. Colli und M. Montinari. Berlin/New York: Walter de Gruyter/DTV, 1999.

NOVALIS. Fragmente und Studien. In: Werke, Tagebücher und Briefe Friedrich von Hardenbergs. Band II. MA"HL, Hans-Joachim und SAMUEL, Richard (Hg.). München/Wien: Carl Hans Verlag, 1978.

OSTARIC, Lara. Works of genius as sensible exhibitions of the idea of the highest good. Kant-Studien, v. 101, 2010.

OvíDIO. Metamorfoses. Trad. Domingos Lucas Dias. São Paulo: Editora 34, 2017.

PICOLI, Gleisy. T. Os limites da linguagem e o místico na filosofia de A. Schopenhauer: Tese de Doutorado em Filosofia. Universidade Estadual de Campinas. Campinas, 2018.

PlATÃO. A república. Trad. Anna Lia Amaral de Almeida Prado. São Paulo: Martins Fontes, 2006.

. Fedro. Trad. José Cavalcante de Souza. São Paulo: Editora 34, 2016.

SCHELLING, Friedrich. W. J. O mais antigo programa sistemático do idealismo alemão. Coleção "Os Pensadores". Trad. Rubens Rodrigues Torres Filho. São Paulo: Editora Abril Cultural, 1979.

Filosofia da arte. Trad. Márcio Suzuki. São Paulo: Edusp, 2001.

SCHLEGEL, Friedrich. Conversa sobre poesia, In: Fragmentos Sobre Poesia e Literatura: 1797-1803 / Conversa Sobre Poesia. Trad. Márcio Suzuki et al. São Paulo: Editora Unesp, 2016.

SCHMIDT, Alfred. Die Wahrheit im Gewande der Lüge: Schopenhauers Religionsphilosophie. München/Zürich: Piper, 1986.

SCHOPENHAUER, Arthur. Sämtliche Werke in fünf Bänden. LÖHNEYSEN, Wolfgang v. (Hrsg). Stuttgart/Frankfurt am Main: Suhrkamp, 1986.

. Metafísica do belo. Trad. Jair Barboza. São Paulo: Editora Unesp, 2001.

O mundo como vontade e representação (Tomo I). Trad. Jair Baborza. São Paulo: Editora Unesp, 2005.

O mundo como vontade e representação (Tomo II). Trad. Jair Barboza. São Paulo: Editora Unesp, 2015.

SELIGMANN-SILVA, Márcio. O local da diferença: ensaio sobre memória, arte, literatura e tradução. São Paulo: Editora 34, 2005.

STAUDT, Leo. Alegoria religiosa e a alegoria na filosofia de Schopenhauer. In: CARVALHO, Ruy et al. (Orgs.). Nietzsche - Schopenhauer: metafísica e significação moral do mundo. Editora da UECE: Fortaleza, 2015.

SøRENSEN, Bengt A. Die "zarte Differenz: Symbol und Allegorie in der asthetischen Diskussion zwischen Schiller und Goethe, In: HAUG, W. Formen und Funktionen der Allegorie. Stuttgart: J.B. Metzler, 1979. 
TORRES FILHO, Rubens. R. O simbólico em Schelling, In: Ensaios de filosofia ilustrada. São Paulo: Editora Brasiliense, 1987.

WACHTER, Allexander. Pólen: Fragmentos, Diálogos, Monólogo. Trad. R. R. Torres Filho. São Paulo: Iluminuras, 1988.

Das Spiel in der Ästhetik: Systematische Überlegungen zu Kants "Kritik der Urteilskraft". Berlin / New York: Walter de Gruyter, 2008.

WINCKELMANN, Johann J. Gedancken über die Nachahnmung der Griechischen Wercke in der Mahlerey und Bildhauer-Kunst. In: Kleine Schriften, Vorreden, Entwürfe. Walter de Gruyter, Berlin, 2002.

Recebido em: 03-08-2018

Aceito para publicação em: 02-11-18 